\title{
BRIEFER COMMUNICATION.
}

\section{HXECUTIVE POWER AND CONSTITUTIONAL AMENDMENT.}

The right of an executive to veto a proposed constitutional amendment has been raised in a case now pending in the Pennsylvania courts. At the 1899 session of the Pennsylvania Legislature, an amendment to the constitution of the state was proposed by the writer opening the way for the introduction of a system of personal registration. The constitutional provision relating to this subject as it stands at present reads as follows :- "No elector shall be deprived of the privilege of voting by reason of his name not being registered." This effectually prevents the introduction of any adequate system of personal registration, such as now prevails in New York, Massachusetts and certain other states. The proposed amendment was passed by the necessary majorities by both houses of the Pennsylvania Legislature and mistakenly sent to the governor for his approval. He vetoed the proposal after the legislature adjourned; so there was no opportunity to pass it over his veto.

The action of the governor was at once questioned by the Municipal League of Philadelphia, which took the necessary steps to test his right in the premises. The provision of the Pennsylvania Constitution relating to amendments reads thus:-(Article I8, section J.)-" Any amendment or amendments to this constitution may be proposed in the senate or house of representatives and if the same shall be agreed to by a majority of the members of each house, such proposed amendment or amendments shall be entered on their journals with the yeas and nays taken thereon and the secretary of the commonwealth shall cause the same to be published three months before the general election in at least two newspapers in every county in which such newspapers shall be published, etc." The governor sustained his right to veto under section 26 of article 3 , which provides that " every order, resolution or vote to which the concurrence of both houses may be necessary, except on the question of adjournment, shall be presented to the governor and before it shall take effect, be approved by him, or being disapproved shall be repassed by two-thirds of both houses, according to the rules and limitations prescribed in the case of a bill."

\section{$[344]$}


The secretary of the commonwealth refused to comply with the constitutional provision, maintaining that the governor's veto was valid; whereupon George Burnham, Jr., president of the Philadelphia Municipal League, petitioned the attorney-general to issue a writ of mandamus directed to the secretary of the commonwealth to show cause why he should not advertise the amendments as provided by the constitution, which petition after argument was granted.

At the hearing before the Dauphin County Court, counsel for the Municipal League set forth that Article I, Section 7, of the Federal Constitution was identical with Article 3, Section 26, of the Constitution of Pennsylvania, and that Article 5 of the Constitution of the United States, relating to amendments, reads as follows: "Congress whenever two-thirds of both houses shall deem it recessary shall propose amendments to this constitution which shall be valid to all intents and purposes as part of this constitution, when ratified by the Legislatures of three-fourths of the several states or by conventions of three-fourths thereof as one or the other mode of ratification shall be proposed by Congress." It was contended that if there was any conflict existing between Section 26, Article 3, and Article 18 of the Pennsylvania Constitution, the same conflict existed between Article I, Section 7, and Article 5 of the Federal Constitution. Inasmuch as the Supreme Court of the United States in the case of Hollingsworth et al. vs. Virginia, 3 Dallas, 378 , decided in substance that there was no conflict between the two last mentioned provisions, that the act of amendment is a substantive act, unconnected with the ordinary business of legislation and was not within the policy or terms of investing the President with a qualified negative of the acts and resolutions of Congress; that the President had no power of approval or disapproval of any proposed constitutional amendment; that he has nothing to do with the proposal or adoption of amendments to the constitution.

Jameson in his work on Constitutional Conventions points out that the amendments to the constitution proposed by Congress in 1789 , 1794, I803 and 1867, were not submitted or presented to the President for his approval, and that the same is substantially true of the amendments relative to slavery proposed by the same body in $186 \mathrm{I}$. In the latter year, however, the amendments proposed by Congress having by inadvertence been presented to the President of the United States for his approval by a subordinate of the Senate, Senator Trumbull of Illinois, Chairman of the Judiciary Committee of that body, introduced the following resolution, which was adopted without division, but after exhaustive argument, in which among others Senator Reverdy Johnson participated: "Resolved that the article of amendment [345] 
proposed by Congress to be added to the Constitution of the United States respecting extinction of slavery therein, having been inadvertently presented to the President for his approval, it is hereby declared that such approval was unnecessary to give effect to the action of Congress in proposing such amendments, inconsistent with the former practice in reference to amendments to the constitution heretofore adopted and being inadvertently done should not constitute a precedent for the future, and the secretary is hereby instructed not to communicate the notice of the approval of such amendment by the President to the House of Representatives."

This unanimous practice under the Federal Constitution has been followed in most if not all of the states, and wherever the question has been brought before the state courts for determination under a similar state of facts, has been determined in accordance with the Federal practice. The latest case dealing with similar provisions was that of the lottery amendments passed upon by the Supreme Court of Louisiana in I8gr. The Constitution of Louisiana provides in words almost identical with the provisions of the Pennsylvania Constitution and of the Federal Constitution "that every order, resolution or vote to which the concurrence of both houses may be necessary, except on a question of adjournment, shall be presented to the governor, and before it shall take effect be approved by him, and being disapproved shall be repassed by two-thirds of the members elected to each house." The provision relating to the proposal of amendments is also substantially the same as the similar provision of the Pennsylvania Constitution. In construing these provisions the Supreme Court of Louisiana in an elaborately prepared series of opinions, after the most careful and exhaustive argument by eminent counsel on both sides, held, that although the Governor of Louisiana had vetoed the proposals in question, the veto had no effect. The court held that the signature of the governor to the proposal for the amendment to the constitution under discussion was not required by the constitution and that his approval of it did not affect its validiiy. State $e x$ rel. Mason, 43 La. Annual.

This decision followed the decision of the Nebraska Supreme Court in, in re Senate File $3 \mathrm{I}, 25 \mathrm{Neb} .887$.

It was pointed out on behalf of the League that the last amendment that had been submitted to the people of Pennsylvania, namely, that of 1889 relating to the abolition of the poll-tax, had been submitted without executive approval. The League's counsel argued the case on the theory that not only had the uniform practice in the various states where similar provisions existed been against the governor's contention and in favor of that of the League, but that the proper 
theory of the governor's veto is that when the people have no chance to express their approval or disapproval of a proposition, then the governor as their representative can intervene his veto, unless an overwhelming proportion of both houses, namely, two-thirds of both branches, should be of the opinion that the proposition should take force and effect. The people themselves, however, have a chance, as the constitution undoubtedly intends that they should have, when it comes to amending their fundamental law. Then the governor's function as a representative of the people in this connection ceases and he has no right to prevent them from approving or disapproving. The final approval or disapproval of constitutional amendments rests with the people. They have never delegated their power over this vitally important matter to any single individual. To save themselves from being annoyed by frivolous, ill-spirited or injudicious amendments, they have agreed not to consider any which cannot command a majority of the members of two legislatures; but this is the only linitation. There is ne conflict between the two provisions of the constitution in question, one relates to legislation, the other to constitutional amendments. One regulates the action of the Legislature, the other the direct legislation of the people. If, therefore, there is no conflict between the two, that provision which relates to and affects the sovereignty of the people themselves, and regulates their action in the most important and solemn matter of government, must prevail over any and all others, else we are brought face to face with the dangers which it was intended to obviate. The change can only be obtained by revolution.

Judge Weiss, of the Dauphin County Court, refused the application for a mandamus and maintained that the proposed amendment to the constitution of the State must be presented to the governor for his approval or disapproval, and that Section 26 of Article 3 and Article I8 should be read into each other. Silence according to his view is not an equivalent and has not the force of an exception. The omission in Article r8, requiring presentation of proposed amendments to the governor for consideration and action is significant, but the omission to except such amendments in Section 26, Article 3, from its operation is of still greater significance, and leads to the conclusion that the provisions of Section 26 were to apply alike to proposed amendments of the constitution and other orders, resolutions and votes. "The proceedings to adopt an amendment to the constitution are legislative in their nature and character. The sovereignty of the people is not called into requisition until the required legislative proceedings are enacted and the governor is an essential factor in all matters relating to legislation. Legislation and amending the [347] 
64 Annals of the American Acadeiry.

constitution seem to us to be alike important and closely interwoven and it is belittling that instrument to characterize legislative authority by it as an ordinary and amending the constitution by some higher designation."

The case has been appealed by the League to the Supreme Court, although the time provided in Article 18 for advertising has passed.

CIINTON ROGERS WOODRUFF. 